\title{
A life cycle environmental sustainability analysis of microbial protein production via power-to-food approaches
}

\author{
J. Sillman ${ }^{1}$ (1) $\cdot$ V. Uusitalo ${ }^{1} \cdot$ V. Ruuskanen ${ }^{1} \cdot$ L. Ojala ${ }^{2} \cdot$ H. Kahiluoto ${ }^{1} \cdot$ R. Soukka ${ }^{1} \cdot$ J. Ahola $^{1}$
}

Received: 19 October 2019 / Accepted: 18 May 2020

(C) The Author(s) 2020, corrected publication 2021

\begin{abstract}
Purpose Renewable energy produced from wind turbines and solar photovoltaics (PV) has rapidly increased its share in global energy markets. At the same time, interest in producing hydrocarbons via power-to-X ( $\mathrm{PtX})$ approaches using renewables has grown as the technology has matured. However, there exist knowledge gaps related to environmental impacts of some PtX approaches. Power-to-food $(\mathrm{PtF})$ application is one of those approaches. To evaluate the environmental impacts of different PtF approaches, life cycle assessment was performed.

Methods The theoretical environmental potential of a novel concept of PtX technologies was investigated. Because PtX approaches have usually multiple technological solutions, such as the studied PtF application can have, several technological setups were chosen for the study. PtF application is seen as potentially being able to alleviate concerns about the sustainability of the global food sector, for example, as regards the land and water use impacts of food production. This study investigated four different environmental impact categories for microbial protein (MP) production via different technological setups of PtF from a cradle-to-gate perspective. The investigated impact categories include global warming potential, blue-water use, land use, and eutrophication. The research was carried out using a life cycle impact assessment method.

Results and discussion The results for PtF processes were compared with the impacts of other MP production technologies and soybean production. The results indicate that significantly lower environmental impact can be achieved with PtF compared with the other protein production processes studied. The best-case PtF technology setups cause considerably lower land occupation, eutrophication, and blue-water consumption impacts compared with soybean production. However, the energy source used and the electricity-to-biomass efficiency of the bioreactor greatly affect the sustainability of the PtF approach. Some energy sources and technological choices result in higher environmental impacts than other MP and soybean production. When designing PtF production facilities, special attention should thus be given to the technology used.

Conclusions With some qualifications, PtF can be considered an option for improving global food security at minimal environmental impact. If the MP via the introduced application substitutes the most harmful practices of production other protein sources, the saved resources could be used to, for example, mitigation purposes or to improve food security elsewhere. However, there still exist challenges, such as food safety-related issues, to be solved before PtF application can be used for commercial use.
\end{abstract}

Keywords Renewable electricity $\cdot$ Life cycle assessment $\cdot$ GHG emissions $\cdot$ Microbial protein $\cdot$ Sustainability $\cdot$ Power-to-food

Shabbir Gheewala

J. Sillman

jani.silman@lut.fi

1 School of Energy Systems, Sustainability Science, LUT University, P.O. Box 20, 53851 Lappeenranta, Finland

2 VTT Technical Research Centre of Finland, P.O. Box 1000, FI-02044 Espoo, VTT, Finland

\section{Introduction}

Natural biogeochemical cycles of the Earth such as the carbon, nitrogen, and phosphorus cycles, as well as the water cycle are disturbed by human activities. The resulting changes in the balance of natural cycles have led to sustainability challenges like global warming, eutrophication, soil salinization, and a decline in available freshwater resources (e.g., The Royal Geographical Society 1998; Vörösmarty et al. 2010). While providing humanity with food, agriculture is a major actor imposing strains on natural cycles and resources (Cambpell 
et al. 2017). Limited arable land and freshwater resources, climate change, and a growing human population are endangering global food security. On current trends, maintaining food security will become increasingly difficult, if present agricultural practices are not adapted to mitigate their effects on natural cycles (Calicioglu et al. 2019; Pretty et al. 2010; Vermeulen et al. 2012). The questions of food security and the environmental impacts of agriculture are well recognized and studied, and there is a need for a shift to a more action-oriented research agenda (Campbell et al. 2016).

Recently, a lot of research has focused on utilization of $\mathrm{CO}_{2}$ into added-value products such as hydrocarbons (Godoy et al. 2017; Khunjar et al. 2012). Hydrocarbons can be produced using bacteria employing the Calvin cycle, in which carbon atoms from $\mathrm{CO}_{2}$ are used to build threecarbon sugars, such as most species of $\mathrm{H}_{2}$-oxidizing bacteria (Kuenen 1999). One focus of previous research has been power-to-X (PtX) technologies to produce hydrocarbons from renewable electricity via water electrolysis and $\mathrm{CO}_{2}$ from different sources (Koj et al. 2019; Chehade et al. 2019). There is no formal definition for PtX applications, but commonly, they refer to technologies producing something from renewable electricity through water electrolysis and additional processes (e.g., Koj et al. 2019; Uusitalo et al. 2017; Zhang et al. 2017). This definition of PtX is used in this paper. The research interest towards PtX is partly due to the forecast rapid growth of renewable energy capacity using energy generation resources such as solar and wind power, and due to environmental challenges, such as anthropogenic climate change and eutrophication, humanity has to solve to move towards sustainable development. The increasing share of renewables does not happen without problems as they cause fluctuation in energy generation resulting in occasional oversupply. To overcome this problem, different demand response solutions are proposed (e.g., Aghaei and Alizadeh 2013; Zehir et al. 2016). Fortunately, PtX applications can be designed to utilize electricity as a demand response, when electricity prices are low, and to balance the grid (Uusitalo et al. 2017; Zhang et al. 2017). Several life cycle assessment studies have shown that PtX processes in most cases lead to reductions in climate change impacts compared to fossil hydrocarbons (e.g., Uusitalo et al. 2017; Zhang et al. 2017; Sternberg and Bardow 2015). Power-to-gas is one example of a PtX application and it is seen as a promising technology for large-scale and long-term energy storage (Zhang et al. 2017).

When considering agricultural products, it is possible to produce bacterial-based protein-rich biomass, also called microbial proteins (MP), for feed and food purposes using a PtX approach. $\mathrm{H}_{2}$-oxidizing bacterium can produce protein-rich biomass suitable for feed or food purposes by utilizing $\mathrm{H}_{2}$, $\mathrm{O}_{2}$, and $\mathrm{CO}_{2}$ with additional substances. $\mathrm{H}_{2}$ and $\mathrm{O}_{2}$ can be produced via water electrolysis and $\mathrm{CO}_{2}$ can be provided from sources such as air. (Sillman et al. 2019) Here, the approach is called a power-to-food $(\mathrm{PtF})$ application. The main components of the PtF approach consist of a $\mathrm{CO}_{2}$ source, bioreactor, water electrolysis, and post-processes for separating biomass from the cultivation medium and for drying. The possibility to produce biomass using the $\mathrm{H}_{2}$-oxidizing bacterium Cupriavidus necator has gained interest in previous studies due to high electricity-to-biomass efficiencies (e.g., Liu et al. 2016; Yu et al. 2013; Yu 2014). In addition, unlike traditional protein production, production of MP is seen as climate independent as the climatic conditions do not influence on the growing conditions of a closed production system and bacterium has a fast growth rate (Upadhaya et al. 2016; Srividya et al. 2014).

The nutritional value of some MP sources, such as MP from $C$. necator, is comparable to nutritional recommendations and to traditional protein sources such as fishmeal and soymeal based on essential amino acids that must be supplied in feed, as the animals themselves cannot synthesize them (Srividya et al. 2014; Volova and Barashkov 2010; WHO/ FAO 1973.). MP from C. necator has been shown to be useful for $25-50 \%$ of the diet depending on the species and age of the animals (Volova and Barashkov 2010). Protein content of bacterial MPs from 50 to $83 \%$ is found in literature. However, the usable protein content is usually lower than the absolute raw protein content of the bacterial biomass. (Anupama and Ravindra 2000; Kunasundari et al. 2013) There are three main types of MP sources, which are fungus, yeast, and bacterial protein. The doubling time of bacterial protein is the fastest among the types of MP sources. (Srividya et al. 2014.) Quorn, spirulina, UniProtein $\AA$, and FeedKind $\AA$ are examples of MP-based products available in the market.

Although bacterial MP is seen as an environmentally sustainable alternative to conventional protein sources, there exist only few MP-related LCA studies focusing on food or feed production. (e.g., Cumberlege et al. 2016; Knudsen et al. 2016). LCA study has been conducted for a bacterial MP known as FeedKind®, which is produced by the biotechnology company Calysta. FeedKind ${ }^{\circledR}$ is a bacterial protein source produced for feed purposes. The bacterium uses methane to build up its biomass, thus it is called MP via methane in this study (Cumberlege et al. 2016). Another example of a MP source that has undergone LCA is microalgae. Their use as food or feed has gained interest in recent years, but the research has mainly focused on their utilization as a raw material for biofuel production (Aresta et al. 2005; Mata et al. 2010; Sander and Murthy 2010; Quin and Davis 2015). Pikaar et al. (2018) used the MagPie model (Pop et al. 2010) to simulate avoided cropland expansion areas, greenhouse gas emissions, and nitrogen pollution impacts of several bacterial MP production pathways. The biggest avoided impacts were gained by using MP via water electrolysis, which is a similar kind of pathway to produce MP than the studied PtF application has. In addition, it has been shown based on quantitative literature review that it is possible to produce MPs with less direct land 
occupation area and freshwater use than conventional protein production by using renewable energy, in situ water electrolysis, direct air capture technology, and post-processes to separate microbial biomass from cultivation medium (Sillman et al. 2019). However, to the extent of our knowledge, there are no LCA studies comparatively evaluating MP production via different $\mathrm{PtF}$ approaches, even though there are several LCA studies focusing on different PtX technologies (Koj et al. 2019). Different PtF approaches have many technological system modifications, of which the energy sources used, origin of substances needed in the production processes, the bacterium species used, and the selected process optimization are a few examples. These technological system differences influence different categories of the environmental life cycle impacts of the production processes; thus, it is essential to know which kind of technological choices should be preferred in terms of environmental sustainability.

As the overall environmental impact of various system modifications of PtF applications is not known, it is necessary to compare how different system modifications impact LCA categories and which approaches have the least environmental impacts. The sustainability can be evaluated by investigating categories related to the planetary boundaries presented in Steffen et al. (2015). The concept of planetary boundaries defines a safe operational zone for humanity for nine environmental activity categories. Water use, land use, biodiversity loss, climate change, and nutrient flows are examples of activities in which agriculture has a major role and which have either exceeded or are close to exceeding safe operation spaces (Cambpell et al. 2017; Steffen et al. 2015). The selected categories for evaluating the sustainability of different modifications of the PtF process are related to climate change, land use, freshwater use, and eutrophication. As regards impacts related to biodiversity loss, there are severe limitations to including biodiversity impacts in LCA methodology (Notamicola et al. 2017). Therefore, biodiversity impacts are not assessed in this study.

The aim of this study is to investigate whether a climateindependent PtF technology can be designed to produce protein-rich biomass that has minimal sustainability impacts compared to other protein-rich sources and, furthermore, to establish which PtF system modifications are the most environmentally sustainable. The hypothesis is that protein via PtF application can be designed to cause less environmental impacts than comparable protein sources. The comparable protein sources are soybean and a few other MPs. Soybean is chosen as it is a widely used plant-based protein source and the nutritional value is comparable with protein via PtF application. Other protein sources are selected to compare the sustainability of PtF to other MPs. If the hypothesis is true, the knowledge can be used for mitigation of the impact of food systems on the natural environment. For instance, by substituting protein sources with higher land use impact with ones having lower land use impact, the saved land could be used, e.g., as sinks for atmospheric $\mathrm{CO}_{2}$. This study provides novel information about how food production can be integrated with electrical power production via PtF applications and information about the environmental impacts of $\mathrm{PtF}$ applications.

\section{Materials and methods}

The study was carried out using a life cycle assessment (LCA) methodology based on the ISO 14040 (2006) standard, and GaBi 6.0 life cycle assessment software was used in the life cycle modeling and impact assessment. A professional database of $\mathrm{GaBi}$ software was used to provide initial data for the model, particularly information related to inputs such as the impact of nutrient and energy production. Additional initial data, for example, the amount of inputs, were gathered from literature.

\subsection{Goal and scope definition}

The aim is to assess four different impact categories related to planetary boundaries. GWP can be used to measure impacts related to climate change. The land occupation indicator is describing land use. Eutrophication potential is describing nutrient flows and blue-water consumption describes freshwater use. Blue-water consumption does not include water scarcity issues. These impacts can be compared with impacts of alternative protein sources.

A base setup was used as a reference for evaluation of the environmental impacts of different modifications of PtF. The base setup is described in Section 2.2.6, and the selected PtF technologies are described in Sections 2.2.1, 2.2.2, 2.2.3, 2.2.4, and 2.2.5. To evaluate the sustainability of the PtF approaches, the environmental impacts of MP production via PtF are compared with other MP products and with conventional plantbased protein sources. In this study, the production of MP via $\mathrm{PtF}$ is assumed to be in Europe. Soybeans are a widely used and efficient plant-based protein source with high protein content and high yields and have similar protein quality than the studied MP, and Europe imports large quantities of soybeans (FAOSTAT 2019; Volova and Barashkov 2010; WHO/FAO 1973). These characteristics make soybean protein a wellsuited protein for comparison. The environmental sustainability comparison between the modeled MP production, other MPs, and soybean protein, based on literature, was performed using an attributional approach. Sensitivity analysis was performed using a one-at-a-time method for base setup.

Different food products are not equal as their nutritional values per kilogram of product vary. Consequently, a direct comparison based only on the weight of the product is unreasonable. Proteins have previously been used to evaluate food security (Diaz-Bonilla et al. 2000) and the idea of MP 
products is to act as substitute proteins for conventional protein sources; thus, $1 \mathrm{~kg}$ of protein is used as a functional unit.

\subsection{Life cycle inventory analysis}

The cultivated bacterium species is $C$. necator (also called Ralstonia eutropha and Alcaligenes eutrophus) (Aragno 1998), which can produce microbial biomass with a usable protein content of 50 to $65 \%$ of dry biomass. (Anupama and Ravindra 2000; Kunasundari et al. 2013; Yu 2014; Volova and Barashkov 2010). In this study, a protein content of $60 \%$ is used when environmental impacts are modeled as the production process is assumed to be designed as close to optimal.

The studied processes for $\mathrm{H}_{2}$-oxidizing-based MP production are amine production, $\mathrm{CO}_{2}$ sources, electricity generation, bioreactors with in situ and external electrolysis, and postprocesses for biomass cultivation and water removal. The production processes are considered closed systems with no runoffs. The closed system refers to a process in which the material and energy flows can be controlled. The controllable processes make it possible to efficiently utilize nutrients with no nutrient run-offs to the surrounding environment. Major material and energy flows are included in the cradle-to-gate assessment. The construction phase of production facilities, minor nutrients in the cultivation medium, and minor unit processes, e.g., cultivation medium pumping into the bioreactor are neglected based on cutoff criteria. As the production facilities can be located nearly everywhere, the logistics impacts are neglected. The system boundary with the different process modifications of the cradle-to-gate assessment is presented in Fig. 1.

\subsubsection{Nutrient and $\mathrm{CO}_{2}$ consumption}

Nutrients included in the LCA models are ammonia, phosphates, and sulfur. Other substances are neglected due to their low concentration in the solution medium and due to data availability issues. The cultivation medium contains several minerals, e.g., $\mathrm{KH}_{2} \mathrm{PO}_{4}$ and $\mathrm{MgSO}_{4}$, with concentrations of a few grams per liter (e.g., Akiyama et al. 2003; Liu et al. 2016; Volova and Barashkov 2010). Based on stoichiometry of production of $1 \mathrm{~kg}$ biomass of $C$. necator, approximately $1.76 \mathrm{~kg}$ of $\mathrm{CO}_{2}$ and 0.16 of $\mathrm{NH}_{3}$ are needed (Liu et al. 2016). The amount of carbon is used to estimate the required amounts of phosphates (P) and sulfur (S). Molar ratios of 1:50 P:C and 0.03:1 S:C are typical for aquatic bacterium (Faberbakke et al. 1996), which accounts for approximately $0.141 \mathrm{~kg}$ of $\mathrm{S}$ and $0.140 \mathrm{~kg}$ of $\mathrm{P}$ per $1 \mathrm{~kg}$ of biomass. Nutrient use and $\mathrm{CO}_{2}$ utilization efficiencies are assumed to be $100 \%$ as the production process can be designed to be a closed system making it possible to utilize nutrients until they are completely depleted (Lee 2015).

$\mathrm{NH}_{3}$ is assumed to be produced by the Haber-Bosch process and the $\mathrm{H}_{2}$ needed is produced from natural gas, which is the most commonly used route to produce $\mathrm{NH}_{3}$. $\mathrm{S}$ is assumed to be derived as a side product from an oil refinery and $\mathrm{P}$ from mineral phosphate containing $32 \%$ of $\mathrm{P}_{2} \mathrm{O}_{5}$. The environmental impacts of $\mathrm{S}, \mathrm{NH}_{3}$, and $\mathrm{P}$ are modeled using average impacts found in the GaBi database for the EU region. A few studies have proposed taking $\mathrm{S}$ and $\mathrm{P}$ from wastewaters (e.g., Matassa et al. 2015). Impacts, if $S$ and $P$ are taken from wastewaters, are studied via one of the system modifications.
Fig. 1 System boundaries of the studied PtF approaches. Boxes with dashed lines represent modifications of $\mathrm{PtF}$ technologies

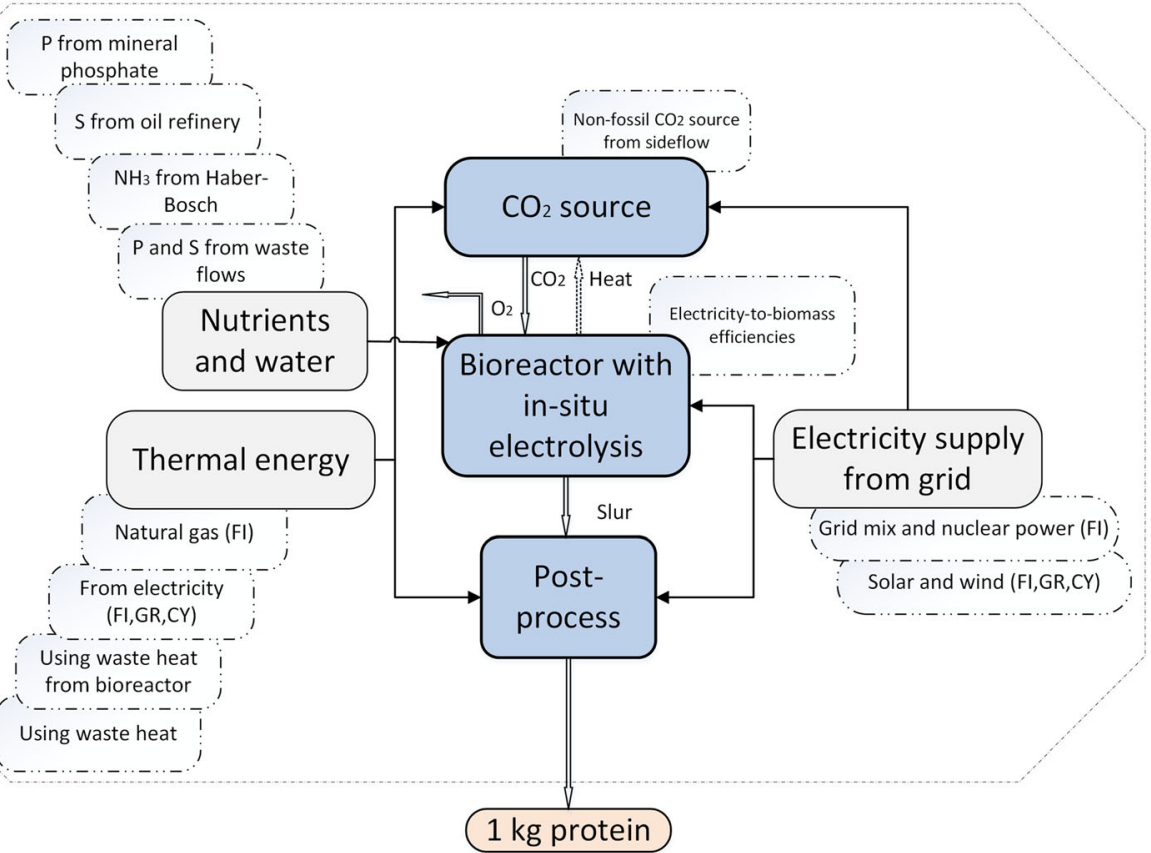




\subsubsection{Electricity and thermal energy generation}

In this study, renewable wind and solar energy are considered as the main electrical energy sources for the PtF applications. However, climatic conditions affect the environmental impacts of renewables, thus the location of electricity generation can have a major role, when thinking overall impacts of PtF applications. To study how latitude affects the overall environmental impacts of PtF systems, the production locations selected for study are in different latitudes in Europe. The used production values are average values of the selected locations, which are Finland, Germany, and Cyprus. Finland represents conditions in Northern Europe, Germany conditions in Central Europe, and Cyprus conditions in Southern Europe. The effect of latitude is studied for renewable energies only. Of course, it is possible to use sources other than wind or solar power for electricity generation, and thus the impacts of nonrenewable electrical energy sources are also studied. Electricity sources compared are solar energy from photovoltaics, wind energy, nuclear energy, and the average electricity mix in Finland. GaBi databases are used to model impacts of electricity production.

Thermal energy is produced using either high-temperature heat pumps, combustion of natural gas, or energy taken from point sources producing waste heat. Natural gas is a widely used fossil fuel-based energy source with relatively low environmental impact; thus, its use is considered in this study. High-temperature heat pumps are preferred over basic heat pumps, because of the required temperature to regenerate amine-based sorbents in the direct air capture (DAC) process (Section 2.2.3). Liu et al. (2016) have estimated that up to 4.54 $\mathrm{kWh}$ thermal energy per kg biomass can be formed in a bioreactor, but $\mathrm{H}_{2}$-oxidizing bacteria grow at relatively low temperatures (approximately $30^{\circ} \mathrm{C}$ ), which makes utilization of the excess heat difficult. Thermal energy created in the bioreactor is thus not considered to be used in this study.

The required electrical energy of heat pumps to produce thermal energy is dependent on the coefficient of performance (COP) value. COP refers to the ratio of useful heating or cooling provided to the work required. A heating COP value of 2.1 to 2.6 has been achieved with a temperature source of 30 to $120{ }^{\circ} \mathrm{C}$ using high-temperature heat pumps but even higher COP values are possible (Arpagaus et al. 2018). In this study, a COP value of 2.5 is used when producing thermal energy using electricity.

\subsubsection{Source of $\mathrm{CO}_{2}$}

Two sources of $\mathrm{CO}_{2}$ are studied in this LCA study. The base setup consists of direct air capture technology (DAC). DAC is seen as a plausible technology capable of reducing $\mathrm{CO}_{2}$ from ambient air that can be used to mitigate climate change (SanzPerez et al. 2016). The second option uses a side flow of pure
$\mathrm{CO}_{2}$ from non-fossil sources without additional material and energy requirements. For example, a fermentation process can supply $\mathrm{CO}_{2}$ to the bioreactor.

DAC technology uses amine-based sorbents to separate $\mathrm{CO}_{2}$ from air. $\mathrm{CO}_{2}$ is absorbed into amines, which can be regenerated at a temperature of approximately $100{ }^{\circ} \mathrm{C}$ (Climeworks 2019). During the regeneration process, the bound $\mathrm{CO}_{2}$ is released and fed to the bioreactor, where the bacterium uses it to build up its biomass. However, small amounts of amines are consumed during the process. The amine production needed has been modeled as described by Zhang et al. (2017). According to Zhang et al. (2017), no information is publicly available regarding the actual processes that are needed to produce the amines used in the Climeworks DAC device. Thus, general organic chemicals are used to estimate environmental impacts from amine production. The amount of consumed organic chemicals is $0.0036 \mathrm{~kg}$ per kilogram of produced biomass, which is calculated using the weight ratio of needed $\mathrm{CO}_{2}$ and consumed organic chemicals. The impacts of amine consumption are estimated by using the $\mathrm{GaBi}$ database of generic organic chemicals including amine. The electricity and thermal energy requirement of the DAC device are $1.8-2.5 \mathrm{kWh} / \mathrm{kg}_{\mathrm{CO} 2}$ and $0.35-0.45 \mathrm{kWh} / \mathrm{kg}_{\mathrm{CO} 2}$, respectively (Climeworks 2019).

$\mathrm{CO}_{2}$ is not the only substance that can be provided by a DAC device. If there is moisture in the air and the air temperature is sufficient, liquid water is formed during the separation process. In humid conditions with a temperature of $+25^{\circ} \mathrm{C}$, the molar ratio of separated $\mathrm{H}_{2} \mathrm{O}$ per $\mathrm{CO}_{2}$ is 4.9 (Elfving et al. 2017). If the separated water does not hold any harmful impurities, it can be used to replace fresh water consumed in production processes. Based on stoichiometry, the amount of formed water is $3.53 \mathrm{~kg}$ per $1 \mathrm{~kg}$ of biomass. In the case of provided $\mathrm{CO}_{2}$, the purity of the $\mathrm{CO}_{2}$ can exceed the purity levels of $99.99 \%$ by volume (IPCC 2005).

\subsubsection{Electricity-to-biomass efficiency of a bioreactor}

Using in situ electrolysis in a bioreactor to grow $\mathrm{H}_{2}$-oxidizing bacterium is an old innovation (Schlegel and Lafferty 1965). Since that time, the electricity-to-biomass efficiency has gradually improved (e.g., Liu et al. 2016; Schuster and Schlegel 1967; Torella et al. 2015). Liu et al. (2016) achieved an efficiency of $54 \%$ by using in situ water electrolysis, which corresponds to $9.86 \mathrm{kWh}$ per produced biomass. In contrast, efficiencies of $4.8 \%$ and $13 \%$ were reported in the studies of Schuster and Schlegel (1967) and Torella et al. (2015), respectively. When studying the environmental impacts, a base situation uses state-of-the-art electricity-to-biomass efficiency with electrical consumption of $9.86 \mathrm{kWh}$. In one case, the electricity-to-biomass efficiency is assumed to be in the range of $13-54 \%$ to demonstrate the importance of the bioreactor 
process on the overall impacts. In that case, the energy consumption is $25 \mathrm{kWh}$ per kilogram of biomass.

The conventional approach for providing a bioreactor with $\mathrm{H}_{2}$ and $\mathrm{O}_{2}$ is to use external water electrolysis rather than in situ electrolysis. In such cases, water electrolysis can be considered as a separate unit process. The challenge of external electrolysis is the low mass transfer of $\mathrm{H}_{2}$ and $\mathrm{O}_{2}$ to aqueous solution, which inhibits the growth rate of bacterial biomass (Yu 2014). In addition to $\mathrm{H}_{2}$ and $\mathrm{O}_{2}$, also $\mathrm{CO}_{2}$ has to be fed into the bioreactor. Typically, the used volumetric ratio of $\mathrm{CO}_{2}, \mathrm{O}_{2}$, and $\mathrm{H}_{2}$ gases for growth of a hydrogen-oxidizing bacterium is 1:2:7 (e.g., Volova et al. 2013; Zhila et al. 2015) and, thus, the amount of $\mathrm{H}_{2}$ and the $\mathrm{H}_{2}$ conversion efficiency to biomass determine the energy requirement of a water electrolysis process. Based on stoichiometry of $C$. necator, the amount of required $\mathrm{H}_{2}$ is $71.4 \mathrm{~g}$ per $\mathrm{kg}_{\text {biomass }}$ (Liu et al. 2016). Matassa et al. (2016) have achieved $\mathrm{H}_{2}$ conversion efficiency of $81 \%$ on average using a continuous reactor type, and thus, the required amount of $\mathrm{H}_{2}$ is $88.1 \mathrm{~g}$ per kg $\mathrm{kg}_{\text {biomass. }}$. In this study, proton exchange membrane (PEM) water electrolysis is used to produce $\mathrm{H}_{2}$ because of its compact structure, wide partial load range, and high energy efficiency (Chi and Yu 2018). The system efficiency of PEM water electrolysis has been reported to vary in a range of $62-77 \%$ defined by the higher heating value (HHV) of hydrogen of $39.41 \mathrm{kWh}$ per $\mathrm{kg}_{\mathrm{H} 2}$ (Decourt et al. 2014). A stack efficiency of $80 \%$ (HHV) has been measured for a commercial $5 \mathrm{~kW}$ PEM stack under differential pressure (Koponen et al. 2017). The Balance of Plant (BOP) energy consumption of the hydrogen production unit has been estimated to be $8 \%$ of the PEM stack energy consumption including the stack power supply losses (Colella et al. 2014). Therefore, the overall energy consumption of the PEM electrolysis based $\mathrm{H}_{2}$ production unit is estimated to be $53 \mathrm{kWh}$ per $\mathrm{kg}_{\mathrm{H} 2}$ and $4.7 \mathrm{kWh}$ per $\mathrm{kg}_{\text {biomass. }}$.

\subsubsection{Post-processes}

The post-processes are designed similarly than described in study Sillman et al. (2019). It can be assumed that the cultivation medium has a biomass concentration of $2.5 \%$ (Lee 2015). First, the concentration of bacterial biomass is increased to $20 \%$ from $2.5 \%$ by the help of centrifugation, thus 401 of cultivation medium needs to be processed. This process requires $0.05 \mathrm{kWh}$ electrical energy per $\mathrm{kg}$ bacterial biomass based on energy consumption of $1.35 \mathrm{kWh}$ per $\mathrm{m}^{3}$ (Davis et al. 2016). Then, the remaining water is evaporated until the biomass concentration is $90 \%$. The evaporation requires approximately $2.91 \mathrm{kWh}$ thermal energy with the efficiency of $84 \%$. After the post-processes the bacterial biomass contains residue water, thus, $0.11 \mathrm{~kg}$ of water is consumed per $\mathrm{kg}$ bacterial biomass. There exist other technical solutions for water removal than evaporation and centrifugation, such as filtration, flash drying, or grinding. In this study, these other technical alternatives are not modeled.

\subsubsection{Studied system modifications}

The base setup acts as a comparative for different system modifications when the environmental impacts are analyzed. The base setup consists of the DAC process, the in situ electrolysis with electricity-to-biomass efficiency of 54\%, the post-processes described in Section 2.2.5 Ammonia is produced via the Haber-Bosch process, sulfur is taken from side flow of an oil refinery, phosphor is taken from mineral phosphate, and the required thermal energy is produced with electricity. The electricity is generated with PV solar power in Finland. The material and energy flows of the base setup of the PtF processes are presented in Table 1.

The study models the base situation and 13 modified technological setups for MP production using the bacterium C. nectator. Country-specific and process-specific data for the modeling are taken from $\mathrm{GaBi}$ databases. Grid mix, plant production, raw material for energy production, and electricity distribution are included in environmental impacts of electricity. When studying the impacts of different electricity sources and locations, the modifications are named according to location and energy source. The system modifications of the PtF processes are presented below:

- Base setup: Material and energy flows are given in Table 1. The selected technologies and energy sources are a bioreactor with in situ electrolysis; solar energy produced in Finland; thermal energy produced using a hightemperature heat pump; DAC is used to provide $\mathrm{CO}_{2}$; and post-processes are designed according to Section 2.2.5.

- Mod1: The electricity-to-biomass efficiency of the bioreactor is changed from 9.86 to $25 \mathrm{kWh}$.

- Mod2: External electrolysis is used instead of in situ electrolysis. Energy flows are modeled according to Section 2.2.4.

- Mod3: The thermal energy for DAC and the postprocesses is produced using natural gas.

- Mod4: The thermal energy is taken from waste heat sources, which are considered emission free.

- Mod5: $\mathrm{S}$ and $\mathrm{P}$ are taken from wastewater flows, which are counted as emission-free sources.

- Mod6: $\mathrm{CO}_{2}$ is taken from waste flows of organic sources (e.g., fermentation). The $\mathrm{CO}_{2}$ is counted as a neutral emission source resulting in zero GHG emissions.

- FInuc: The electricity used is nuclear energy in Finland.

- FIwin: The electricity used is wind power in Finland.

- FImix: The electricity used is the grid mix in Finland.

- CYsol: The electricity used is photovoltaic solar power in Cyprus.

- CYwin: The electricity used is wind power in Cyprus. 
Table 1 Energy and material flows of processes of the base situation per $1 \mathrm{~kg}$ of produced biomass

\begin{tabular}{|c|c|c|c|c|c|c|}
\hline \multicolumn{7}{|c|}{ Direct air capture } \\
\hline \multirow[t]{2}{*}{ Inputs } & Electricity $[\mathrm{kWh}]^{\mathrm{a}}$ & Thermal energy $[\mathrm{kWh}]^{\mathrm{a}}$ & Organic chemicals $[\mathrm{kg}]^{\mathrm{b}}$ & & Air* & \\
\hline & 0.71 & 3.78 & $0.0036 \mathrm{SSSS}$ & & & \\
\hline \multirow[t]{2}{*}{ Outputs } & $\mathrm{CO}_{2}[\mathrm{~kg}]$ & water_cond $[\mathrm{kg}]$ & & & & \\
\hline & 1.76 & 3.53 & & & & \\
\hline \multicolumn{7}{|c|}{ Bioreactor } \\
\hline \multirow[t]{2}{*}{ Inputs } & Electricity [kWh] & Mineral phosphate $[\mathrm{kg}]$ & Sulfur $[\mathrm{kg}]$ & Ammonia $[\mathrm{kg}]$ & $\mathrm{CO}_{2}[\mathrm{~kg}]$ & Water $[\mathrm{kg}]$ \\
\hline & $9.86^{\mathrm{c}}$ & $0.140^{\mathrm{d}}$ & $0.14^{\mathrm{d}}$ & $0.16^{\mathrm{c}}$ & $1.76^{\mathrm{c}}$ & $0.11^{\mathrm{c}}$ \\
\hline \multirow[t]{2}{*}{ Outputs } & Biomass $[\mathrm{kg}]$ & $\mathrm{O}_{2}[\mathrm{~kg}]$ & & & & \\
\hline & 1 & $1.31^{\mathrm{c}}$ & & & & \\
\hline \multicolumn{7}{|c|}{ Post-process } \\
\hline \multirow[t]{2}{*}{ Inputs } & Electricity $[\mathrm{kWh}]$ & Thermal energy $[\mathrm{kWh}]$ & & & & \\
\hline & $0.39^{\mathrm{e}}$ & $2.91^{\mathrm{e}}$ & & & & \\
\hline \multirow[t]{2}{*}{ Outputs } & Biomass $[\mathrm{kg}]$ & Water $[\mathrm{kg}]$ & & & & \\
\hline & 1 & $0.11^{\mathrm{c}}$ & & & & \\
\hline
\end{tabular}

${ }^{\mathrm{a}}$ Climeworks (2019), ${ }^{\mathrm{b}}$ Zhang et al. (2017), ${ }^{\mathrm{c}}$ (Liu et al. 2016), ${ }^{\mathrm{d}}$ Section 2.2.1, ${ }^{\mathrm{e}}$ Section 2.2 .5 , *amount of air is not measured, but the amount of separated water and $\mathrm{CO}_{2}$ are known

- GEsol: The electricity used is photovoltaic solar power in Germany.

- GEwin: The electricity used is wind power in Germany.

\subsubsection{Other reference systems: soybean and selected MP productions}

FeedKind ${ }^{\circledR}$ is a bacterial MP using methanogenesis to build up its biomass. The powder form of FeedKind®, which does not hold any substances other than bacterial biomass has a carbon footprint of $2.229 \mathrm{~kg}_{\mathrm{CO} 2}$ per $\mathrm{kg}_{\text {protein }}$ but can achieve a lower carbon footprint value if the natural gas used in the process is replaced with biogas. Water consumption for the powder form of FeedKind $囚$ is approximately $10 \mathrm{~kg}$ water per $\mathrm{kg}$ protein, and land occupation is $0 \mathrm{~m}^{2}$ per $\mathrm{kg}$ protein. (Cumberlege et al. 2016). The average value of protein content of Quorn, mycoprotein, is $0.16 \mathrm{~kg}$ per $\mathrm{kg}$ product, which is used to evaluate environmental impacts of mycoprotein production. Mycoprotein has global warming potential (GWP) and land use values of 38.4-15 $\mathrm{kg}_{\mathrm{CO}-\mathrm{eq}}$ and 2.6-7.5 $\mathrm{m}^{2}$ per $\mathrm{kg}$ protein, respectively (Head et al. 2011; Smetana et al. 2015). Water requirement for mycoprotein production and eutrophication values for MP via methane and mycoprotein production were not found in literature.

Soybean is one of the most important plant-based protein source for feed and human food (FAOSTAT 2019). However, it has been reported to have various negative environmental impacts, for example, from land use in tropical regions (e.g. Barona et al. 2010; Fearnside 2001). Eutrophication, land use, water use, and GWP impacts of soybean production are highly dependent on the production practices used and the growing location, and thus the values used for comparison does not cover all the production practices there are. However, they provide directional estimate for impacts of soybean production. Protein content of soybean from varies 32 to $43 \%$ per $\mathrm{kg}$ product. Average protein content of $35 \%$ per kilogram of soybeans (Damian et al. 1999; Dornbos and Mullen 1992) is used for impact estimations on soybean production. Comparable eutrophication value of soybean protein production for Pequivalent is $0.019 \mathrm{~kg}$ per $\mathrm{kg}$ protein (Jekeyinfa et al. 2013). Climate change impact varies from 0.89 to $3.74 \mathrm{~kg}_{\mathrm{CO} 2 \text {-eq }}$ per $\mathrm{kg}$ protein, and land use varies from 5.24 to $6.04 \mathrm{~m}^{2}$ per kilogram of annual protein production. Water consumption of soybean production is approximately $6.3 \mathrm{~kg}$ of water per kg protein (Adom et al. 2012; da Silva et al. 2010; Mekonnen and Hoekstra 2012).

\subsection{Life cycle impact analysis}

The GaBi software is designed to measure different impacts on the environment rather than the impact allowed within planetary boundaries. However, knowledge gained from LCA studies can be used to design systems that cause the least impact on the environment. By substituting systems with high environmental impacts with those having less impact, the overall burden on the environment decreases and the system moves towards the safe operation space. In this paper, the environmental impacts of protein production is the system studied. 
Global warming potential, land occupation indicator, eutrophication potential, and blue-water consumption are modeled for every system modification. GWP and eutrophication potential are modeled using CML 2001-2015 GWP 100 weighting and the land occupation indicator is used to model land use. Blue-water consumption includes freshwater consumption and excludes rainwater. The water use has been calculated using weight as a measure and it does not account for regionalized impact in terms of water scarcity.

\section{Results}

Global warming potential, land occupation indicator, eutrophication potential, and blue-water consumption of PtF system modifications are investigated in Section 3.1. The results are discussed in Section 3.1.5.

\subsection{GWP, land occupation, eutrophication, and blue- water consumption of system modifications}

Life cycle GWP, land occupation, eutrophication, and bluewater consumption of different system modifications are presented in Sections 3.1.1, 3.1.2, 3.1.3, and 3.1.4. The different system modifications are compared to the base situation to ascertain critical processes as regards the studied impacts. The impacts of different system modifications are modeled from Mod 1 to Mod 6. For modifications named FI, CY, or GE, only electricity sources and the location of energy production have been changed. For each system variation, a bestcase technological setup is formed based on the best-case scenario in the impact category of GWP.

\subsubsection{Global warming potential}

For the different technological setups of PtF, the electricity-tobiomass efficiency of the bioreactor and the method used to provide the process with thermal energy and $\mathrm{CO}_{2}$ have the greatest influence on GWP. Of the studied systems, the bestcase scenario is to use point sources of waste heat and external water electrolysis and to take the required $\mathrm{CO}_{2}$ and nutrients $\mathrm{S}$ and $\mathrm{P}$ from side flows. The least favorable solutions are to use low electricity-to-biomass efficiency bioreactors and a DAC process using natural gas as a thermal energy provider (Fig. 2).

The electricity source has the biggest impact on the GWP, as seen in Fig. 2. FInuc has the lowest impact and the highest impact is found with FImix. FInuc uses nuclear power and FImix uses the current grid mix in Finland as the energy source. However, because of the increasing interest of PtX processes using renewables are increasing, this study focus on impacts of renewables. The availability of solar and wind energy is dependent on climate conditions, and the location of the production facilities thus has an impact on GWP when wind or solar energy sources are relied on. Only FImix using the Finnish grid mix as the energy source causes higher GWP impact than the base situation. Wind energy and solar energy in southern latitudes cause the lowest GWP impact values of the studied renewable energy sources.

When combining the best-case system modifications of the studied systems using solar and wind energy in different locations, the MP production causes approximately $1.00 \mathrm{~kg}_{\mathrm{CO} 2}$ eq $\mathrm{kg}_{\text {protein }}{ }^{-1}$ and $0.81 \mathrm{~kg} \mathrm{~kg}_{\mathrm{CO} 2 \text {-eq }} \mathrm{kg}_{\text {protein }}{ }^{-1}$ in Cyprus, 1.11 $\mathrm{kg}_{\mathrm{CO} 2 \text {-eq }} \mathrm{kg}_{\text {protein }}{ }^{-1}$ and $0.83 \mathrm{~kg}_{\mathrm{CO} 2 \text {-eq }} \mathrm{kg}_{\text {protein }}{ }^{-1}$ in Germany, and $1.15 \mathrm{~kg}_{\mathrm{CO} 2 \text {-eq }} \mathrm{kg}_{\text {protein }}{ }^{-1}$ and $0.82 \mathrm{~kg}_{\mathrm{CO} 2 \text {-eq }} \mathrm{kg}_{\text {protein }}{ }^{-1}$ in Finland, respectively. The best-case system modifications consist of external water electrolysis and waste or side flow sources of $\mathrm{CO}_{2}$, thermal energy, and nutrients. Ammonia production has a high impact value in the best-case system modifications, accounting for $64-90 \%$ of total GWP impacts.

\subsubsection{Land occupation indicator}

The studied system modifications in Fig. 3 show that the electricity used and the thermal energy source have the greatest influence on the land occupation indicator. The impacts caused by production facilities are neglected. The nutrients $\mathrm{S}, \mathrm{P}$, and $\mathrm{NH}_{3}$ have low impact on the land occupation indicator. In best-case system modifications, described in Section 3.1.1, the impacts of PtF using solar energy and wind energy are $0.060 \mathrm{~m}^{2} \mathrm{~kg}_{\text {protein }}{ }^{-1}$ year $^{-1}$ and $0.029 \mathrm{~m}^{2} \mathrm{~kg}_{\text {protein }}{ }^{-1}$ year $^{-1}$ in Cyprus, $0.084 \mathrm{~m}^{2} \mathrm{~kg}_{\text {protein }}{ }^{-1}$ year $^{-1}$ and $0.036 \mathrm{~m}^{2}$

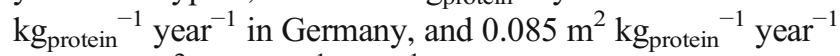
and $0.031 \mathrm{~m}^{2} \mathrm{~kg}_{\text {protein }}{ }^{-1}$ year $^{-1}$ in Finland, respectively.

\subsubsection{Eutrophication potential}

The impact of the eutrophication potential of the different system modifications was modeled for $\mathrm{P}$ equivalent. Ammonia production and the used electricity source have the greatest impact on eutrophication (Fig. 4). The best-case setup resulted in $0.000333 \mathrm{~kg}_{\mathrm{P}-\mathrm{eq}} \mathrm{kg}_{\text {protein }}{ }^{-1}$ and was found for wind energy in Cyprus.

\subsubsection{Blue-water consumption}

Of the studied impact categories, the blue-water consumption shows the biggest difference for the studied system modifications (Figs. 3, 4, and 5). Although direct water consumption is highest in the bioreactor process, in most of the cases the biggest life cycle water consumption is caused by electricity generation and DAC processes. The water consumption in the process is around 0.81 per produced $\mathrm{kg}_{\text {protein }}$ (Table 1). Using solar energy as an energy source consumes significantly more water compared to the solution using wind energy. The bestcase setup using wind or solar energy resulted in $1 \mathrm{~kg}_{\text {water }} \mathrm{kg}$ protein $^{-1}$ and $3.8 \mathrm{~kg}_{\text {water }} \mathrm{kg}_{\text {protein }}{ }^{-1}$ in Cyprus, respectively. 


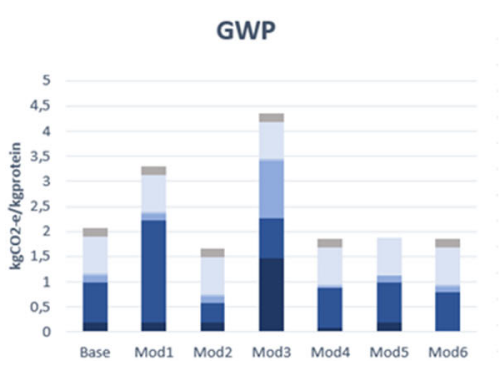

Fig. 2 Global warming potential of different system modifications of PtF application. PtF application with different material sources and technologies (left). The sensitivity of electricity source and location to

\subsubsection{Environmental impacts of PtF setups compared to other protein sources}

When comparing impacts of best-case system modifications for bacterial MP produced via PtF in Cyprus to the impacts of other protein sources taken from literature (Section 2.2.7; Table 2), it can be seen that PtF-based MP production causes minimal environmental impacts with only the life cycle blue water consumption being higher than that of soybean protein production. GWP of PtF protein is lower than MP via methane, Quorn, and the average GWP value of soybean production. The best-case systems can cause between two to two and a half times lower GWP impacts compared to the average impact of soybean production. In the case of land use, the $\mathrm{PtF}$ process has significant advantages compared to mycoprotein and soybean production and has the same kind of land requirements as MP via methane. Life cycle water consumption can be designed to be lower than MP via methane and soybean production but using PV as an energy source consumes significantly more blue water than using wind as the energy source. Considering only the process stoichiometry, the process can produce more water than it consumes, if DAC is implemented in humid conditions. The production of MP consumes approximately $0.18 \mathrm{~kg}$ of water per $\mathrm{kg}$ protein and produces approximately $5.89 \mathrm{~kg}$ of water per $\mathrm{kg}$ protein. The capacity to produce water can be beneficial in areas having a high demand for water but limited water resources. In the case of the eutrophication, PtF causes tenfold less eutrophication impact than soybean production.

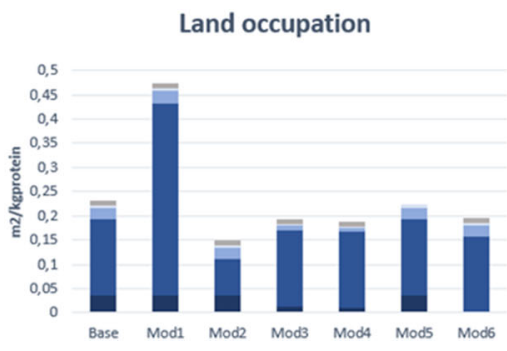

Fig. 3 Land occupation of different system modifications of PtF application. The land occupation indicator estimates the annual area required for protein production. PtF application with different material
Different sources of electricity

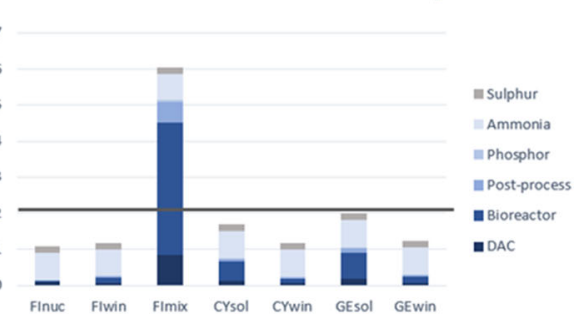

overall impacts (right). Highlighted horizontal bar shows GWP value of the reference base setup

\section{Discussion}

The LCA in this study shows that compared to soybean production, bacterial biomass can produce protein many times faster with less water use, lower land area requirements, less eutrophication, and lower GWP impacts. Especially the bestcase setups of the studied technologies can produce highquality bacterial-based protein with significantly reduced environmental impacts. Even when best-case setups of PtF applications are not used, the environmental impacts in the studied categories are in many cases smaller than the other protein sources studied (Table2; Figs. 2, 3, 4, and 5). The exception is blue-water consumption, especially when solar energy and DAC is used, but then again, the direct water consumption is not so great. Therefore, the PtF technology has many design options causing relatively small environmental impacts. The flexible design can be beneficial from the perspective of optimal design for local resources and local climate conditions. For instance, the production system can be designed as a closed system, and as such, it will not cause nutrient runoff to the environment. In addition, the production is location and climate independent (Srividya et al. 2014).

The life cycle assessment consists of the major material and energy flows of the PtF applications based on secondary data found in literature and by manufacturers. The impacts of amine consumption of the DAC process are based on estimates of generic organic chemicals; thus, the impacts of precise amine-based chemicals should be investigated. The facilities for MP production, minor nutrients in the cultivation

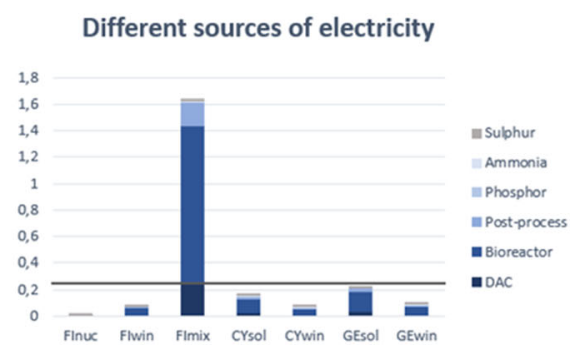

sources and technologies (left). The sensitivity of electricity source and location to overall impacts (right). Highlighted horizontal bar shows Land occupation indicator value of the reference base setup 


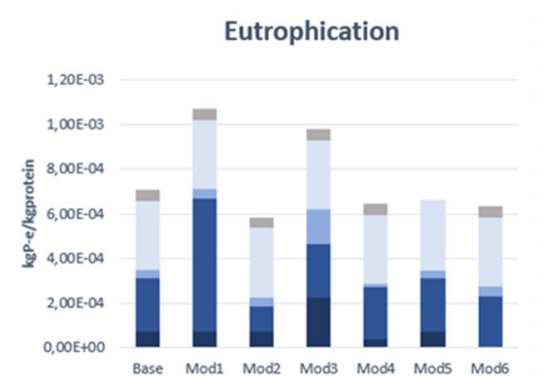

Fig. 4 Eutrophication values based on phosphorus equivalent of PtF systems. Material and energy inputs and outputs of energy production and substance needs are included in the life cycle analysis. PtF applications with different material sources and technologies (left). The

medium and minor unit processes were omitted from the study. In addition, the safety-related aspects, such as contamination and $\mathrm{pH}$ control, might slightly cause impacts during the maintenance, which were also omitted. The cumulative impacts of these omitted materials, unit processes, and facilities should be investigated, to gain a better understanding of the lifetime impacts of the PtF applications. The energy and material requirement of the studied bioreactors were laboratory-scale reactors; thus, the material and energy requirement of bioreactors with larger capacity should be tested, although scaling up the capacity would appear to be unproblematic (Reed et al. 2015). Overall, this study gives valuable information when designing sustainable PtF systems.

The countries of the EU import millions of tons of soymeal and soybeans for food and feed purposes. Most of the imported soybeans and soymeal comes from the United States of America and South America. Imports from South America are problematic as there are many sustainability challenges related to soy crop production, for instance, challenges related to soybean farming in former rainforest areas (Barona et al. 2010; Fearnside 2001). By substituting imported soymeal and soybeans produced in South America with protein produced via a PtF system, many environmental impacts can be alleviated, and the food production system can move towards remaining within planetary boundaries as regards climate change, nutrient flows, water use, and land use. It should be noted that the results of this study give an overview of the impacts but do not account for all indirect

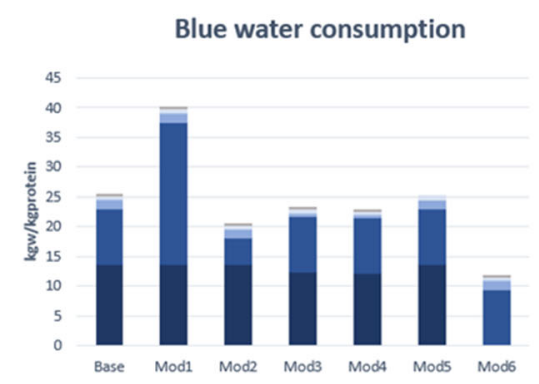

Fig. 5 Blue-water consumption values of PtF systems. Material and energy inputs and outputs of energy production and substance needs are included in the life cycle analysis. PtF applications with different material
Different sources of electricity

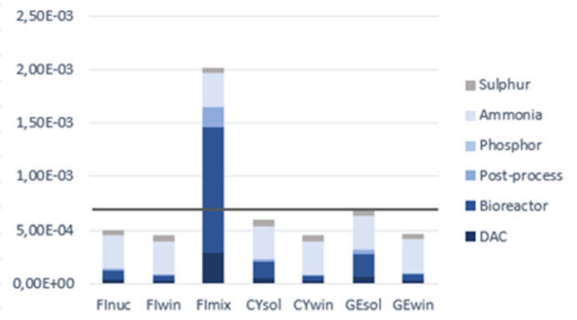

sensitivity of electricity source and location to overall impacts (right). Highlighted horizontal bar shows the eutrophication value of the reference base setup

impacts in transition from one protein source to another. In addition, the amount of substitutable protein is limited and protein from soybean is not the only source the MP via PtF can substitute. For example, Pikaar et al. (2018) estimate that approximately $10-19 \%$ of the protein content in feed is substitutable. However, the MP via PtF is not yet commercialized; thus, the production process must undergo several safety-related tests before it can be used either for food or feed purposes (Dominique et al. 2016).

Although biodiversity is a major category in environmental impact analysis, it is not quantitatively researched in this study. Biodiversity is not commonly studied in life cycle impact assessments due to difficulties measuring biodiversity impact reliably without knowledge of local conditions (Notamicola et al. 2017). However, as pesticides and herbicides are not used in the PtF production processes (Srividya et al. 2014) and there is a possibility to use non-arable land for production facilities, there is a strong indication that the biodiversity impact of MP production is minimal compared to traditional protein production in agriculture. For instance, the worldwide reduction in insects is one alarming indicator of the collapse of our surrounding biodiversity. The main drivers of insect reduction are intensive agriculture and widespread use of pesticides (Sánchez-Bayo and Wyckhuys 2019; Geiger et al. 2010). Furthermore, the majority of soybeans and soymeal imported to the EU originates from South America, mainly Brazil and Argentina. These areas have been identified as being at risk of loss of biodiversity due to increased

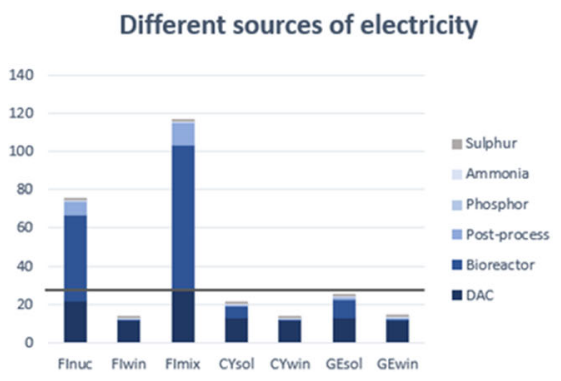

sources and technologies (left). The sensitivity of electricity source and location to overall impacts (right). Highlighted horizontal bar shows bluewater consumption value of the reference base setup 
Table 2 Environmental impact values of different protein sources

\begin{tabular}{lllll}
\hline & $\mathrm{GWP}\left[\mathrm{kg}_{\mathrm{CO} 2 \text {-eq }} \mathrm{kg}_{\text {protein }}{ }^{-1}\right]$ & $\mathrm{LU}\left[\mathrm{m}^{2} \mathrm{a} \mathrm{kg}_{\text {protein }}{ }^{-1}\right]$ & $\begin{array}{l}\text { Water use } \\
{\left[\mathrm{kg}_{\text {water }} \mathrm{kg}_{\text {protein }}{ }^{-1}\right]}\end{array}$ & $\begin{array}{l}\text { Eutrophication } \\
{\left[\mathrm{kg}_{\text {P-eq }} \mathrm{kg}_{\text {protein }}{ }^{-1}\right]}\end{array}$ \\
\hline $\mathrm{MP}_{\text {PtF wind }}$ & 0.81 & 0.029 & 1.01 & 0.00033 \\
$\mathrm{MP}_{\text {PtF solar }}$ & 1.00 & 0.060 & 3.75 & 0.00039 \\
$\mathrm{MP}_{\text {Methane }}$ & $2.23^{\mathrm{a}}$ & $0^{\mathrm{a}}$ & $10^{\mathrm{a}}$ & - \\
Mycoprotein & $15-38.4^{\mathrm{bc}}$ & $2.6-7.5^{\mathrm{bc}}$ & - & - \\
Soybean & $0.89-3.74^{\mathrm{de}}$ & $5.24-6.04^{\mathrm{d}}$ & $6.3^{\mathrm{f}}$ & $0.016^{\mathrm{g}}$ \\
\hline
\end{tabular}

${ }^{\mathrm{a}}$ Cumberlege et al. (2016), ${ }^{\mathrm{b}}$ Head et al. (2011), ${ }^{\mathrm{c}}$ Smetana et al. (2015), ${ }^{\mathrm{d}}$ da Silva et al. (2010), ${ }^{\mathrm{e}}$ Adom et al. (2012), ${ }^{\mathrm{f}}$ Mekonnen and Hoekstra (2012), ${ }^{\mathrm{g}}$ Jekeyinfa et al. (2013) pressures from soy production (WWF 2014). Future research is needed on how PtF for MP affects biodiversity and its potential to free land from crop production for other purposes, for example, as carbon sinks by afforestation.

When utilizing nutrients from waste flows, as suggested, for example, by Matassa et al. (2015) and Matassa $a_{a}$ et al. (2016), questions remain regarding safety aspects of product sterility (Ritala et al. 2017). However, according to results gained from LCA, using wastewaters as $\mathrm{P}$ and $\mathrm{S}$ sources causes only a small reduction in the studied impact categories, and thus, there is no significant environmental benefit gained by using wastewaters. In the case of the ammonia or ammoniac source, most of today's $\mathrm{NH}_{3}$ is produced with the HaberBosch process using natural gas as an energy source and to provide $\mathrm{H}_{2}$ to the process. Thus, only $\mathrm{NH}_{3}$ from natural gas was considered in this study. Current practice for $\mathrm{NH}_{3}$ production is fossil dependent and has high environmental impact (Udvardi et al. 2015). However, it is possible to produce $\mathrm{NH}_{3}$ by supplying $\mathrm{H}_{2}$ using alternative technologies, which may reduce the environmental impacts of $\mathrm{NH}_{3}$ production (e.g., Murakami et al. 2005). For example, ammonium sulfate can be recovered from biogas digestate at the sanitation phase. The process has lower systemic energy cost than $\mathrm{NH}_{3}$ production with the Haber-Bosch process (Törnwall et al. 2017). $\mathrm{NH}_{3}$ can also be recovered directly from the biogas digester through a semi-permeable membrane, which not only produces ammonia but also improves the digester efficiency (Lauterböck et al. 2014). In view of these alternative $\mathrm{NH}_{3}$ production methods, the possibility of reducing the impacts of PtF by using novel production practices for $\mathrm{NH}_{3}$ supply should be investigated.

Electricity generation and the unit process consuming most of the electricity, i.e. the bioreactor with electrolysis, have a major effect on the studied environmental impacts. Thus, for the PtF application to be more sustainable than other comparable protein sources, the source of electricity should be chosen carefully. For example, FImix using the grid mix in Finland as an electricity source for the PtF application causes higher GWP, land occupation, and blue-water consumption values than soybean production, even though a major part of the Finnish grid mix consists of renewables and nuclear energy. As regards the electricity-to-biomass efficiency of the bioreactor, the use of external water electrolysis can result in lower energy consumption than using in situ electrolysis, but there are safety aspects that need to be considered. For example, the gases fed to the reactor may ignite, when they are in contact with measurement instruments in the bioreactor, causing an explosion (C\&EN 2016). In addition to the electricity source and bioreactor efficiency, the source of $\mathrm{CO}_{2}$ has a pronounced effect on the overall sustainability of the PtF process. If there are no reasonable point sources of pure $\mathrm{CO}_{2}$, using DAC can be beneficial. DAC can separate water from air, making the process produce more water than it consumes. Water separation could be advantageous in areas having high water demand. However, using DAC increases the environmental impacts by approximately $10 \%$ as the unit process consumes energy and amines. Nevertheless, a PtF setup with a DAC unit process may have less environmental impact than other sources of protein.

Different PtX applications are usually energy-intensive technologies (Koj et al. 2019; Sternberg and Bardow 2015) and PtF is not an exception. It could be argued that the PtX technologies with the least environmental impacts and the least energy-consuming solutions should be preferred to limit the increase of energy demand (e.g. Sternberg and Bardow 2015). However, there are several aspects that should also be considered. For instance, what products from PtX technologies should replace and what different kinds of environmental impacts should be considered, when making the choices. In the case of protein from PtF technology, there are several impact categories that are relevant in the agricultural sector. Land use, water use, fertilizers use, and biodiversity related impacts can each be the most important impact category depending on what product and where the product is produced. Another aspect is that is the limit of possible renewable energy an issue. It is known that the potential of renewables exceeds many times the energy needs of humankind; thus, it is theoretically possible to construct $100 \%$ renewable energy systems (e.g., Barbosa et al. 2017; Connoly et al. 2016).

Electricity consumption in MP production via the PtF approach is higher than in soybean production. However, the trend of the price of renewable energy is falling and 
production of bacterial MP could be balanced according to the varying production and load of the grid, leading to reduced electricity costs, and/or incentive payments (Zehir et al. 2016). A possible future increase in the cost of food might transform production costs in favor of MP production. Thus, a topic of great interest would be to research the critical tipping point for the economic feasibility of PtF for MP production. Such research should also include techno-economic assessment to establish the best economical setup of PtF application in different locations.

\section{Conclusions}

The PtF process can be designed so that it causes significantly lower environmental impacts in all the studied categories than most of the other studied protein sources. Major environmental benefits can be gained from substituting conventional protein sources with MP produced via PtF technology. In particular, the land occupation indicator is minimal compared to soybean production, which brings the possibility of converting land currently used for crop production to other purposes, for instance, with afforestation, which can be used for carbon sinks and to tackle biodiversity losses. However, the environmental sustainability of PtF depends greatly on the electricity source used and the electricity-to-biomass efficiency of the bioreactor. In addition, before PtF technology is commercially feasible, techno-economic assessment should be done and larger production capacity reactors should be piloted. Overall, it can be concluded that producing MP via a PtF process has the potential to reduce the environmental burden of agriculture and play a role in mitigation and adaptation to climate change.

Acknowledgments Open access funding provided by LUT University. This work was supported by the Academy of Finland for providing funding for the study Smart Energy Transition - Realizing its potential for sustainable growth for Finland's second century (SET) [grant number 293405].

\section{Compliance with ethical standards}

Conflict of interest The authors declare that they have no conflict of interest.

Open Access This article is licensed under a Creative Commons Attribution 4.0 International License, which permits use, sharing, adaptation, distribution and reproduction in any medium or format, as long as you give appropriate credit to the original author(s) and the source, provide a link to the Creative Commons licence, and indicate if changes were made. The images or other third party material in this article are included in the article's Creative Commons licence, unless indicated otherwise in a credit line to the material. If material is not included in the article's Creative Commons licence and your intended use is not permitted by statutory regulation or exceeds the permitted use, you will need to obtain permission directly from the copyright holder. To view a copy of this licence, visit http://creativecommons.org/licenses/by/4.0/.

\section{References}

Adom F, Maes A, Workman C, Clayton-Niederman Z, Thoma G, Shonnard D (2012) Regional carbon footprint analysis of dairy feeds for milk production in the USA. Int J Cycle Assess 17:520-534. https://doi.org/10.1007/s11367-012-0386-y

Aghaei J, Alizadeh M-I (2013) Demand response in smart electricity grids equipped with renewable energy sources: A review. Renew Sustain Energ Rev 18:64-72. https://doi.org/10.1016/j.rser.2012.09.019

Akiyama M, Tsuge T, Doi Y (2003) Environmental life cycle comparison of polyhydroxyalkanoates produced from renewable carbon resources by bacterial fermentation. Polym Degrad Stab 80(1):183194. https://doi.org/10.1016/S0141-3910(02)00400-7

Anupama, Ravindra P (2000) Value-added food: Single cell protein. Biotechnol Adv 18(6):459-479. https://doi.org/10.1016/S07349750(00)00045-8

Aragno M (1998) The aerobic, hydrogen-oxidizing (knallgas) bacteria. In: Burlage RS, Atlas R, Stahl D, Geesey G, Sayler G (eds) Techniques in microbial ecology. Oxford University Press, New York, pp 3917-3933

Aresta M, Dibenedetto A, Barberio G (2005) Utilization of macro-algae for enhanced $\mathrm{CO}_{2}$ fixation and biofuels production: Development of computing software for an LCA study. Fuel Process Technol 86(1415):1679-1693. https://doi.org/10.1016/j.fuproc.2005.01.016

Arpagaus C, Bless F, Uhlmann M, Schiffmann J, Bertsch SS (2018) High temperature heat pumps: Market overview, state of the art, research status, refrigerants, and application potentials. Energy 152:9851010. https://doi.org/10.1016/j.energy.2018.03.166

Barbosa LSNS, Bogdanov D, Vainikka P, Breyer C (2017) Hydro, wind and solar power as a base for a $100 \%$ renewable energy supply for South and Central America. PLoS One 12(3):e0173820. https://doi. org/10.1371/journal.pone. 0173820

Barona E, Ramankutty N, Hyman G, Coomes T (2010) The role of pasture and soybean in deforestation of the Brazilian Amazon. Environ Res Lett 5(2). https://doi.org/10.1088/1748-9326/5/2/024002

C\&EN (2016) Spark from pressure gauge caused University of Hawaii explosion, fire department says. Chemical \& Engineering News. http://cen.acs.org/articles/94/web/2016/04/Spark-pressure-gaugecaused-University.html. Accessed 1 August 2018

Calicioglu O, Flammini A, Bracco S, Bellu L, Sims R (2019) The future of food and agriculture: an integrated analysis of trends and solutions. Sustainability-Basel 11(1). https://doi.org/10.3390/su11010222

Cambpell BM, Beare DJ, Bennett EM, Hall-Spencer JM, Ingram JSI, Jaramillo F, Ortiz R, Ramankutty N, Sayer JA, Shindell D (2017) Agriculture production as a major driver of the Earth system exceeding planetary boundaries. Ecol Soc 22(4):8. https://doi.org/10.5751/ ES-09595-220408

Campbell BM, Vermeulen SJ, Aggarwall PK, Cornell-Dollof C, Girvetz E, Loboguerrero AM, Ramirez-Villegas J, Rosenstock T, Sebastian L, Thornton PK, Wollenberg E (2016) Reducing risks to food security from climate change. Glob Food Secur Agric 11:34-43. https:// doi.org/10.1016/j.gfs.2016.06.002

Chehade Z, Mansilla C, Lucchese P, Hilliard S, Proost J (2019) Review and analysis of demonstration projects on power-to-X pathways in the world. Int J Hydrogen Energ 44(11):27637-27655. https://doi. org/10.1016/j.ijhydene.2019.08.260

Chi J, Yu H (2018) Water electrolysis based on renewable energy for hydrogen production. Chin J Catal 39(3):390-394. https://doi.org/ 10.1016/S1872-2067(17)62949-8

Climeworks (2019) Facts \& figures. www.climeworks.com/facts-figures. html. Accessed 1 Septemper 2019

Colella WG, James BD, Moton JM, Saur G, Ramsden T (2014) Technoeconomic Analysis of PEM Electrolysis for Hydrogen Production. Electrolytic Hydrogen Production Workshop, NREL, Colorado

Connoly D, Lund H, Mathiesen BV (2016) Smart Energy Europe: the technical and economic impact of one potential $100 \%$ renewable 
energy scenario for the European Union. Renew Sust Energ Rev 60: 1634-1653. https://doi.org/10.1016/j.rser.2016.02.025

Cumberlege T, Blenkinsopp T, Clark J (2016) Assessment of environmental impact of FeedKind protein Carbon Trust. https://www.carbontrust. com/media/672719/calysta-feedkind.pdf. Accessed 10 May 2019

da Silva VP, Van der Werf HMG, Spies A, Soares SR (2010) Variability in environmental impacts of Brazil Soybean according to crop production and transport scenarios. J Environ Manag 91(9):1831-1839. https://doi.org/10.1016/j.jenvman.2010.04.001

Damian MM, Labuckas DO, Meriles JM, Lamarque AL, Zygadlo JA, Guzman CA (1999) Seed composition of soybean cultivars evaluated in different environmental regions. J Sci Food Agric 77(4):494498. https://doi.org/10.1002/(SICI)1097-0010(199808)77:4<494:: AID-JSFA69>3.0.CO;2-B

Davis R, Markham J, Kinchin C, Grundl N, Tan ECD, Humbird D (2016) Process Design and economics for the production of algal biomass: algal biomass production in open pond systems and processing through dewatering for downstream conversion. National Renewable Energy Laboratory, Denver

Decourt B, Lajoie B, Debarre R, Soupa O (2014) Hydrogen-based energy conversion: More than Storage: System Flexibility. The SBC Energy Institute, Paris

Diaz-Bonilla E, Marcelle T, Sherman R, Andrea C (2000) Food security and trade negotiations in the World Trade Organization. TMD discussion papers 59. International Food Policy Research Institute (IFPRI), Washington

Dominique T, Bresson J-L, Burlingame B, Dean T, Fairweather-Tait S, Heinonen M, Hirsch-Ernst K et al (2016) Guidance on the preparation and presentation of an application for authorization of a novel food in the context of Regulation (EU) 2015/2283. EFSA J 14(11). https://doi.org/10.2903/j.efsa.2016.4594

Dornbos DL, Mullen RE (1992) Soybean seed protein and oil contents and fatty acid composition adjustments by drought and temperature. J Am Oil Chem Soc 69(3):228-231. https://doi.org/10.1007/BF02635891

Elfving J, Bajamundi C, Kauppinen J, Sainio T (2017) Modelling of equilibrium working capacity of PSA, TSA and TVSA processes for CO 2 adsorption under direct air capture conditions. J CO2 Util 22:270-277

Faberbakke KM, Heldal M, Norland S (1996) Content of carbon, nitrogen, oxygen, sulfur and phosphorous in native aquatic and cultured bacteria. Aquat Microb Ecol 10(1):15-27. https://doi.org/10.3354/ame010015

FAOSTAT (2019) Crops. www.fao.org/faostat/en/\#data/QC. Accessed 10 march 2019

Fearnside PM (2001) Soybean cultivation as a threat to the environment in Brazil. Environ Conserv 28(1):23-38. https://doi.org/10.1017/ S0376892901000030

Geiger F, Bengtsson J, Berendse F, Weisser WW, Emmerson M, Morales MB, Ceryngier P, Liira J, Tscharntke T, Winqvist C, Eggers S, Bommarco R, Pärt T, Bretagnolle V, Plantegenest M, Clement LW, Dennis C, Palmer C, Oñate JJ, Guerrero I, Hawro V, Aavik T, Thies C, Flohre A, Hänke S, Fischer C, Goedhart PW, Inchausti P (2010) Persistent negative effects of pesticides on biodiversity and biological control potential on European farmland. Basic Appl Ecol 11(2):97-105. https://doi.org/10.1016/j.baae.2009.12.001

Godoy MS, Mongili B, Fino D, Prieto MA (2017) About how to capture and exploit the $\mathrm{CO}_{2}$ surplus that nature, per se, is not capable of fixing. Microb Biotechnol 10(5):1216-1225. https://doi.org/10. 1111/1751-7915.12805

Head M, Sevenster M, Croezen H (2011) Life cycle impacts of proteinrich foods for Superwijzer. https://www.cedelft.eu/publicatie/life cycle_impacts_of_protein-rich_foods_for_the_superwijzer_app/ 1264. Accessed 10 May 2019

IPCC Special Report on Carbon Dioxide Capture and Storage (2005) Prepared by Working Group III of the Intergovernmental Panel on Climate Change [Metz, B., O. Davidson, H. C. de Coninck, M. Loos, and L. A. Meyer (ed.)]. Cambridge University Press, Cambridge, United Kingdom and New York, NY, USA
ISO International Organization for Standards. EN ISO 14040:2006. Environmental management. Life cycle assessment. Principles and framework

Jekeyinfa SO, Olarinan JA, Sasanya BF (2013) Life Cycle assessment of soybeans production and processing system into soy oil using solvent extraction process. Int J Cycle Assess 12(7):235-245. https:// doi.org/10.1504/IJPLM.2013.063203

Khunjar WO, Sahin A, West AC, Chandran K, Banta S (2012) Biomass Production from Electricity Using Ammonia as an Electron Carrier in a Reverse Microbial Fuel Cell. PLoS One 7(9):e44846. https:// doi.org/10.1371/journal.pone.0044846

Knudsen MT, Dorca-Preda T, Hermansen JE (2016) Life Cycle Assessment of Alternative Protein Sources: Constraints and Potentials. In: Andersen K, Tybirk K (eds) Nordic Alternative Protein Potentials: Mapping of regional bioeconomy opportunities. Nordic Council of Ministers, Denmark

Koj JC, Wulf C, Zapp P (2019) Environmental impacts of power-to-X systems - a review of technological and methodological choices in life cycle assessments. Renew Sust Energ Rev 112:865-879. https:// doi.org/10.1016/j.rser.2019.06.029

Koponen J, Kosonen A, Ruuskanen V, Huoman K, Niemelä M, Ahola J (2017) Control and energy efficiency of PEM water electrolyzers in renewable energy systems. Int J Hydrog Energy 42(50):29648-29660

Kuenen G (1999) Oxidation of inorganic compounds by chemolithotrophs. In: Lengeler JW, Drews G, Schlegel HG (eds) Biology of the prokaryotes. Georg Thieme Verlag, Stuttgard, pp 187-233

Kunasundari B, Murugaiyah V, Kaur G, Maurer FHJ, Sudesh K (2013) Revisiting the Single Cell Protein Application of Cupriavidus necator H16 and recovering bioplastic granules simultaneously. PLoS One 8(10):e78528. https://doi.org/10.1371/journal.pone.0078528

Lauterböck B, Nikolausz M, Lv Z, Baumgartner M, Liebhard G, Fuchs W (2014) Improvement of anaerobic digestion performance by continuous nitrogen removal with a membrane contactor treating a substrate rich in ammonia and sulfide. Bioresour Technol 158:209-216. https://doi.org/10.1016/J.BIORTECH.2014.02.012

Lee BH (2015) Fundamentals of food biotechnology, 2nd edn. John Wiley \& Sons, Chichester

Liu C, Colón BC, Ziesack M, Silver PA, Nocera DG (2016) Water splitting-biosynthetic system with $\mathrm{CO}_{2}$ reduction efficiencies exceeding photosynthesis. Science 352(6290):1210-1213. https:// doi.org/10.1126/science.aaf5039

Mata TM, Martins AA, Caetano NS (2010) Microalgae for biodiesel production and other applications: a review. Renew Sust Energ Rev 14(1):217-232. https://doi.org/10.1016/j.rser.2009.07.020

Matassa S, Boon N, Verstraete W (2015) Resource recovery from used water: the manufacturing abilities of hydrogen-oxidizing bacteria. Water Res 68(1):467-478. https://doi.org/10.1016/j.watres.2014.10.028

Matassa S, Boon N, Pikaar I, Verstraete W (2016) Microbial protein: future sustainable food supply route with low environmental footprint. Microb Biotechnol 9(5):568-575. https://doi.org/10.1111/1751-7915.12369

Matassaa S, Verstraete W, Pikaar I, Boon N (2016) Autotrophic nitrogen assimilation and carbon capture for microbial protein production by a novel enrichment of hydrogen-oxidizing bacteria. Water Res 101: 137-146. https://doi.org/10.1016/j.watres.2016.05.077

Mekonnen MM, Hoekstra Y (2012) A global assesment of the water footprint of farm animal products. Ecosystems 15:401-415. https://doi.org/10.1007/s10021-011-9517-8

Murakami T, Nohira T, Goto T, Ogata YH, Ito Y (2005) Electrolytic ammonia synthesis from water and nitrogen gas in molten salt under atmospheric pressure. Eletrochim Acta 50(27):5423-5426. https:// doi.org/10.1016/j.electacta.2005.03.023

Notamicola G, Sala S, Anton A, Mclaren SJ, Saouter E, Sonesson U (2017) The role of life cycle assessment in supporting sustainable agri-food systems: a review of the challenges. J Clean Prod 140(1): 399-409. https://doi.org/10.1016/j.jclepro.2016.06.071 
Pikaar I, Matassa S, Bodirsky BL, Weindl I, Humpenöder F, Rabaey K, Boon N, Bruschi M, Yuan Z, van Zanten H, Herrero M, Verstraete W, Popp A (2018) Decoupling livestock from land use through industrial feed production pathways. Environ Sci Technol 52(13): 7351-7359. https://doi.org/10.1021/acs.est.8b00216

Pop A, Lotze-Camben H, Bodirsky B (2010) Food consumption, diet shifts and associated non- $\mathrm{CO}_{2}$ greenhouse gases from agricultural production. Glob Environ Chang 20(3):451-462. https://doi.org/10. 1016/j.gloenvcha.2010.02.001

Pretty J, Sutherland WJ, Ashby J, Auburn J, Baulcombe D, Bell M, Bentley J, Bickersteth S, Brown K, Burke J, Campbell H, Chen K, Crowley E, Crute I, Dobbelaere D, Edwards-Jones G, Funes-Monzote F, Godfray HCJ, Griffon M, Gypmantisiri P, Haddad L, Halavatau S, Herren H, Holderness M, Izac AM, Jones M, Koohafkan P, Lal R, Lang T, McNeely J, Mueller A, Nisbett N, Noble A, Pingali P, Pinto Y, Rabbinge R, Ravindranath NH, Rola A, Roling N, Sage C, Settle W, Sha JM, Shiming L, Simons T, Smith P, Strzepeck K, Swaine H, Terry E, Tomich TP, Toulmin C, Trigo E, Twomlow S, Vis JK, Wilson J, Pilgrim S (2010) The top 100 questions of importance to the future of global agriculture. Int J Agric Sustain 8(4):219-236. https:// doi.org/10.3763/ijas.2010.0534

Quin JC, Davis R (2015) The potentials and challenges of algae based biofuels: a review of thechno-economic, life cycle, and resource assessment modelling. Bioresour Technol 184:444-452. https:// doi.org/10.1016/j.biortech.2014.10.075

Reed J, Geller J, McDaniel R (2015) $\mathrm{CO}_{2}$ Conversion by Knallgas Microorganisms. California Energy Commission. Publication number: CEC-500-2017-005

Ritala A, Häkkinen ST, Toivari M, Wiebe MG (2017) Single Cell protein-state-of-the-art, industrial landscape and patents 2001-2016. Front Microbiol 8. https://doi.org/10.3389/fmicb.2017.02009

Sánchez-Bayo F, Wyckhuys KAG (2019) Worldwide decline of the entofauna: a review of its drivers. Biol Conserv 232:8-27. https:// doi.org/10.1016/j.biocon.2019.01.020

Sander K, Murthy GS (2010) Life cycle analysis of algae biodiesel. Int J Cycle Assess 15(7):704-714. https://doi.org/10.1007/s11367-010-0194-1

Sanz-Perez ES, Murdock CR, Didas SA, Jones CW (2016) Direct air capture of $\mathrm{CO}_{2}$ from ambient air. Chem Rev 116(19):11840 11876. https://doi.org/10.1021/acs.chemrev.6b00173

Schlegel HG, Lafferty R (1965) Growth of 'knallgas' bacteria (hydrogenomonas) using direct electrolysis of the culture medium. Nature 205:308-309. https://doi.org/10.1038/205308b0

Schuster E, Schlegel HG (1967) Chemolitotrophes Wachstum von Hydrogenomonas H16 im Chemostaten mit elektrolytischer Knallgaserzeugung. Arch Microbiol 58:380-409. https://doi.org/ 10.1007/BF00409745

Sillman J, Nygren L, Kahiluoto H, Ruuskanen V, Tamminen A, Bajamundi C, Wuokko M, Lindh T, Vainikka O, Pitkänen J-P, Ahola J (2019) Bacterial protein for food and feed via renewable energy and direct air capture of $\mathrm{CO}_{2}$ : Can it reduce land and water use? Glob Food Secur Agric 22:25-32. https://doi.org/10.1016/j.gfs.2019.09.007

Smetana S, Mathys A, Knoch A, Heinz V (2015) Meat alternatives: life cycle assessment of most known meat substitutes. Int J Cycle Assess 20(9):1254-1267. https://doi.org/10.1007/s11367-015-0931-6

Srividya AR, Vishnuvarthan VJ, Murugappan M, Dahake PG (2014) Single cell protein- a review. IJPRS 2(4):472-485 Manuscript no: IJPRS/V2/I4/00278

Steffen W, Richardson K, Rockström J, Cornell SE, Fetzer I et al (2015) Planetary boundaries: guiding human development on a changing planet. Science 347(6223):1259855. https://doi.org/10.1126/science.1259855

Sternberg A, Bardow A (2015) Power-to-What? Environmental analysis of energy storage systems. Energy Environ Sci 8:389-400. https:// doi.org/10.1039/C4EE03051F

The Royal Geographical Society (1998) Global environmental change: the causes and consequences of disruption to biogeochemical cycles. Geogr J 164(2):168-182. https://doi.org/10.2307/3060368
Torella JP, Gagliardi CJ, Chen JS, Bediako DK, Colon B, Way JC, Silver P, Nocera DG (2015) Efficient solar-to-fuels production from a hybrid microbial-water-splitting catalyst system. PNAS 112(8):23372342. https://doi.org/10.1073/pnas.1424872112

Törnwall E, Pettersson H, Thorin E, Schwede S (2017) Post-treatment of biogas digestate - an evaluation of ammonium recovery, energy use and sanitation. Energy Procedia 142:957-963. https://doi.org/10. 1016/J.EGYPRO.2017.12.153

Udvardi M, Brodie EL, Riley W, Keappler S, Lynch J (2015) Impacts of agricultural nitrogen on the environment and strategies to reduce these impacts. Procedia Environ Sci 29:303. https://doi.org/10. 1016/j.proenv.2015.07.275

Upadhaya S, Tiwari S, Arora NK, Singh DP (2016) Microbial protein: a valuable component for future food security. In: Singh JK, Singh DP (eds) Microbes and Environmental Management. Studium Press, New Delhi, pp 259-279

Uusitalo V, Väisänen S, Inkeri E, Soukka R (2017) Potential for greenhouse gas emission reductions using surplus electricity in hydrogen, methane and methanol production via electrolysis. Energy Convers Manag 134:125-134. https://doi.org/10.1016/j.enconman.2016.12.031

Vermeulen SJ, Aggarwal PK, Ainslie A, Angelone A, Campbell BM, Challinor AJ, Hansen JW, Ingram JSI, Jarvis A, Kristjanson P, Lau C, Nelson GC, Thornton PK, Wollenberg E (2012) Options for support to agriculture and food security under climate change. Environ Sci Policy 15(1):1136-1144. https://doi.org/10.1016/j. envsci.2011.09.003

Volova TG, Barashkov VA (2010) Characteristics of proteins synthesized by hydrogen-oxidizing microorganisms. Appl Biochem Micro+46(6)

Volova TG, Kislev EG, Shishatskaya EI, Zhila NO, Boyandin AN, Syrvacheva DA, Vinogradova ON, Kalacheva GS, Vasilev AD, Peterson IV (2013) Cell growth and accumulation of polyhydroxyalkanoates from $\mathrm{CO} 2$ and $\mathrm{H} 2$ of a hydrogen-oxidizing bacterium, Cupriavidus eutrophus B10646. Bioresour Technol 146: 215-222. https://doi.org/10.1016/j.biortech.2013.07.070

Vörösmarty CJ, McIntyre PB, Gessner MO, Dudgeon D, Prusevich A, Greem P, Glidden S, Bunn SE, Sullivan CA, Reidy Liermann C, Davies PM (2010) Global threats to human water security and river biodiversity. Nature 467:555-561. https://doi.org/10.1038/ nature 09549

WHO/FAO (1973) Energy and protein requirement. World Health Organization. FAO nutrition meeting report series No. 52 and WHO Technical report series No 522. Geneva

WWF (2014) The growth of soy impacts and solutions: impacts and solutions. WWF International, Gland, Switzerland

$\mathrm{Yu} \mathrm{J}$ (2014) Bio-based products from solar energy and carbon dioxide. Trends Biotechnol 32(1):5-10. https://doi.org/10.1016/j.tibtech. 2013.11.001

Yu J, Dow A, Pingali S (2013) The energy efficiency of carbon dioxide fixation by a hydrogen-oxidizing bacterium. Int J Hydrogen Energ 38(21):8683-8690. https://doi.org/10.1016/j.ijhydene.2013.04.153

Zehir NA, Batman A, Bagriyanik M (2016) Review and comparison of demand response options for more effective use of renewable energy at consumer level. Renew Sust Energ Rev 56:631-642. https://doi. org/10.1016/j.rser.2015.11.082

Zhang X, Bauer C, Mutel CL, Volkart (2017) Life cycle assessment of power-to-gas: approaches, system variations and their environmental implications. Appl Energy 190(15):326-338. https://doi.org/10. 1016/j.apenergy.2016.12.098

Zhila N, Kalacheva G, Volova T (2015) Fatty acid composition and polyhydroxyalkanoates production by Cupriavidus eutrophus B10646 cells grown on different carbon sources. Process Biochem 50(1):69-78. https://doi.org/10.1016/j.procbio.2014.10.018

Publisher's note Springer Nature remains neutral with regard to jurisdictional claims in published maps and institutional affiliations. 